\section{Politicians still only talking}

\section{Boston}

IN a week marked by vocal debate over global climate change, a group of representatives from private foundations gathered quietly with scientists and international security experts in Cambridge, Massachusetts, last week to explore the international political fallout from anticipated changes in the environment.

While British Prime Minister Margaret Thatcher called upon the UN General Assembly to lead the way in worldwide action, and environmental policy-makers from 68 nations gathered in the Netherlands failed to agree on international limits on carbon-dioxide emissions, those meeting in Cambridge tackled social and legal issues such as the prospect that drastic climate change could produce 'environmental refugees' and the idea that environmental concerns could become so crucial that countries would be justified in overriding the sovereignty of others to enforce protective measures.

At the Cambridge meeting, which was sponsored by the American Academy of Arts and Sciences, the presence of representatives of some of the largest private US foundations signalled a mounting interest in global change research. Although no new financial commitments were announced at the meeting, several foundations, including the John D. and Catherine T. MacArthur Foundation and the Social Science Research Council, have already earmarked funds specifically for research on global environmental change.

But dissent over political choices overshadowed scientific uncertainty. The scientists present agreed that precise and consistent models of global climate change are decades away, but nonetheless presented a fairly uniform and troubling consensus about the threats posed by ozone depletion and trapped greenhouse gases. It was the social scientists and security experts who clashed most severely in their assessment of the political implications of the issue.

Some, like George Rathjens, professor at the Center for International Studies at the Massachusetts Institute of Technology, argued that the economic costs involved in curbing emissions may be too high to allow immediate action, and that the costs "diminish the prospects for international agreements". But others declared that "we know enough now" to justify a push for international cooperative measures - even coercive measures.

Speaking unofficially on behalf of the Brazilian government, Eunice Durham, an anthropologist at the University of São Paulo, bristled at even the notion of international coercion or pressure to reduce global warming. In the view of the Brazilian government, said Durham, "military action [would be] justified" if the nation's sovereignty over the Amazon rain forest is in any way challenged. Furthermore, she added, deforestation "is not going to be stopped unless there is a viable alternative development plan for the region". Similar divisions and disagreements emerged at the international conference in the Netherlands. Despite President George Bush's claims of the need for a "war against global warming", the United States, together with Japan and the Soviet Union, led the way in thwarting the endorsement of a specific timetable for

\section{GLOBAL KNOWLEDGE}

\section{Washington}

WhEN George Bush and Mikhail Gorbachev meet upon the Mediterranean Sea next month, they will be on equal terms in at least one respect: their respective countrymen will have an equally vague idea of where in the world they are. Asked to identify 16 locations on the map below, US citizens got an average of 8.6 correct, and Soviets did a little worse, scoring 7.4. Swedes and West Germans did best (11.6 and 11.2 correct identifications); the Japanese averaged 9.7 and the British 8.5.

The results of the survey, conducted by the Gallup organization for the National Geographic Society specifically to compare knowledge of geography in ten countries, have been taken in the United States as more evidence that the educational system, no matter how many brilliant scholars it may produce, is failing the general popula- curbs on emissions of carbon dioxide. Most of the 68 countries present at the Netherlands environmental conference wanted to freeze allowable emissions of carbon dioxide by the year 2000 .

William K. Reilly, head of the US Environmental Protection Agency, stressed the fact that the United States agreed in principle to the need for international emission levels. But many critics in the United States and elsewhere were disappointed at the outcome of the Netherlands meeting, and criticized the United States for its deliberate inaction. As one critic put it, the US position made Bush's strong statements about global warming look like "a lot of hot air". Seth Shulman

\title{
Americans and Russians mostly at sea
}

tion. For Americans, the most alarming result of the country-identification quiz was that the youngest age-group (18-24) did significantly worse than the rest of the population: for the other countries, younger people tended to do as well as or better than their elders. Last year, an international survey put US high school students near the bottom of the class in science (see Nature 332, 195; 1988).

But the Soviets, if the responses of 1,500 inhabitants of Moscow and Kursk reflect the knowledge of the population as a whole, have even more reason for alarm. Although 88 per cent of the Soviet sample had taken a geography course in school, and 61 per cent thought geographical knowledge a necessity, their achievements belied these ideals. Only 38 per cent of the Soviets knew where Afghanistan was.

David Lindley

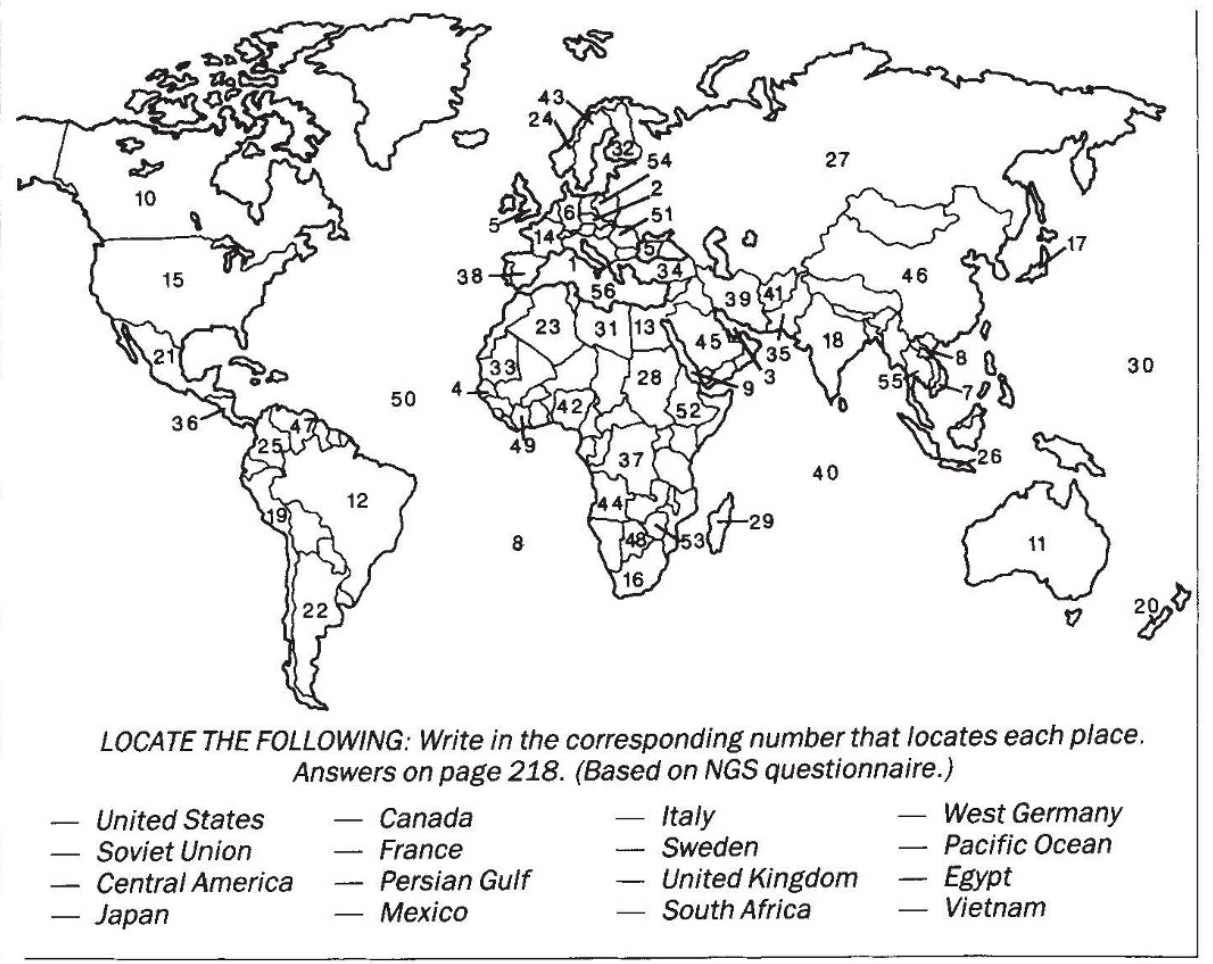

